Kumawula, Vol. 4, No.1, April 2021, Hal 92 - 97

DOI: https://doi.org/10.24198/kumawula.v4i1.32162

ISSN 2620-844X (online)

Tersedia online di http://jurnal.unpad.ac.id/kumawula/index

\title{
PEMBERDAYAAN MASYARAKAT DALAM PEMBUATAN BURONCONG TABARO SOLUSI PENINGKATAN EKONOMI DI TENGAH COVID-19
}

\author{
Salju $^{1}$, Harmita Sari ${ }^{2 *}$, Altri Wahida ${ }^{3}$, Indra Kusdarianto ${ }^{4}$ \\ ${ }^{1}$ Program Studi Manajemen, Universitas Muhammadiyah Palopo \\ ${ }^{2}$ Program Studi Manajemen, Universitas Muhammadiyah Palopo \\ ${ }^{3}$ Program Studi Manajemen, Universitas Muhammadiyah Palopo \\ ${ }^{4}$ Program Studi Manajemen, Universitas Muhammadiyah Palopo
}

*Korespondensi: harmitasari93@gmail.com

\begin{abstract}
Buroncong tabaro is one of the traditional dishes of South Sulawesi made from sago, which is made by many people. Generally, buroncong is made from wheat flour. Seeing the large production of sago in North Luwu District is the reason for the writer to innovate buroncong using sago as the basic material. With the processing of sago as raw material for tabaro buroncong, it can minimize the cost of raw materials which of course will affect the selling price of tabaro buroncong and can create new ways of consuming sago which is generally only consumed as a substitute for staple foods such as limestone, sinole, and dange. The objectives and targets of the activities of this community empowerment program are as a means of helping the community to maximize the production of processed food made from sago which can be used as an alternative business in increasing people's income. Sago-based buroncong tabaro has a relatively cheap price compared to other buroncong which is made from wheat flour without compromising the taste and quality of the buroncong itself. As for the implementation of the activities carried out, namely the demonstration of making tabaro buroncong. The results of activities in community empowerment are that the community is able to make traditional buroncong tabaro food preparations, package products with attractive and hygienic designs and implement good business management and increase a high entrepreneurial spirit.
\end{abstract}

Keywords: Community Empowerment; Sago; Buroncong Tabaro, Covid-19

\begin{abstract}
ABSTRAK
Buroncong tabaro merupakan salah satu makanan tradisional khas Sulawesi Selatan berbahan dasar sagu yang pembuatannya cukup banyak digeluti masyarakat. Buroncong pada umumnya berbahan dasar tepung terigu. Melihat besarnya produksi sagu di Kabupaten Luwu Utara menjadi alasan penulis untuk menginovasikan buroncong dengan menggunakan bahan dasar sagu. Dengan adanya pengolahan sagu sebagai bahan baku buroncong tabaro, dapat meminimalisasi biaya bahan baku yang tentunya akan memengaruhi harga jual buroncong tabaro serta dapat menciptakan cara baru dalam mengonsumsi sagu yang umumnya hanya dikonsumsi sebagai pengganti makanan pokok seperti kapurung, sinole, dan dange. Tujuan dan target hasil kegiatan program pemberdayaan masyarakat ini adalah sebagai sarana dalam membantu masyarakat untuk memaksimalkan produksi makanan olahan berbahan dasar sagu yang dapat dijadikan sebagai alternatif usaha dalam meningkatkan pendapatan masyarakat. Buroncong tabaro berbahan dasar sagu memiliki harga yang relatif murah dibandingkan buroncong pada umumnya yang berbahan dasar tepung terigu tanpa mengurangi rasa dan kualitas buroncong itu sendiri. Adapun pelaksanaan kegiatan yang dilakukan yaitu demonstrasi pembuatan buroncong tabaro. Hasil kegiatan dalam pemberdayaan masyarakat yaitu masyarakat mampu membuat olahan makanan tradisional buroncong tabaro, mengemas produk dengan desain menarik dan higienis serta menerapkan manajemen usaha yang baik dan meningkatkan jiwa berwirausaha yang tinggi.
\end{abstract}

Kata kunci: Pemberdayaan Masyarakat; Sagu; Buroncong Tabaro; Covid-19 


\section{PENDAHULUAN}

Kabupaten Luwu Utara merupakan kabupeten pemekaran dari Kabupaten Luwu Raya pada tahun 1999 dibentuk berdasarkan UU No.19 tahun 1999. Kabupaten Luwu Utara berbatasan dengan beberapa daerag. Di sebelah utara berbatasan dengan Sulawesi Tengah, di sebelah barat berbatasan dengan Sulawesi Barat dan Tana Toraja dan di sebelah timur berbatasan dengan Kabupaten Luwu dan teluk Bone. Secara astronomis Kabupaten Luwu Utara terletak antara $01^{\circ} 53^{\prime} 1^{\prime \prime}-02^{\circ} 55^{\prime} 36^{\prime \prime}$ LS dan $119^{\circ} 47^{\prime} 46^{\prime \prime}-120^{\circ} 37^{\prime}$ 44" BT (Hamid, Ridha and Madjid, 2019).

Salah satu desa yang terletak di Kabupaten Luwu Utara yaitu Desa Kapidi Kecamatan Mappedeceng. Secara astronomis Desa Kapidi terletak pada koordinat $2^{\circ} 37^{\prime} 05^{\prime \prime}$ 2'39'22" LS dan $120^{\circ} 21^{\prime} 52^{\prime \prime}-120^{\circ} 24^{\prime} 03^{\prime \prime}$ BT. Desa Kapidi berada di tengah-tengah Kecamatan Mappedeceng. Jarak antara Desa Kapidi dengan Ibu Kota Kabupaten Luwu Utara adalah $11 \mathrm{~km}$ serta kurang lebih $469 \mathrm{~km}$ dari Ibu Kota Provinsi Sulawesi Selatan. Desa Kapidi berbatasan langsung di sebelah utara dengan Desa Cendana Putih II, di sebelah timur dengan Desa Cendana Putih I, sebelah selatan dengan Desa Ujung Mattajeng, dan sebelah barat dengan Kecamatan Masamba. Desa Kapidi terdiri atas 5 dusun dan 10 RT yaitu Dusun Kapidi, Dusun Sumber Ase, Dusun Sumber Ase Selatan, Dusun Sapuraga, dan Dusun Labeka. Dengan sektor penggunaan lahan yang didominasi oleh persawahan dan perkebunan (Darsana, 2019).

Mayoritas penduduk di Desa Kapidi adalah bekerja sebagai petani. Luas lahan pertanian di desa ini mencapai 17 ha. Adapun jenis pertanian yang diusahakan oleh masyarakat pada umumnya adalah tanaman pangan seperti padi, kakao, kelapa sawit, lada, durian, sagu, dan rambutan. Jika dilihat dari segi luas lahan perkebunan maka yang menjadi tanaman/produksi unggulan yaitu tanaman sayur-sayuran, buah-buahan, dan tanaman obatobatan (Luwuutarakab.go.id, 2018).

Tabaro atau yang sering dikenal dengan nama sagu, tumbuh di Desa Kapidi secara alamiah, tidak ada upaya dari masyarakat dan pemerintah untuk membudidayakan tanaman sagu. Sagu merupakan salah satu sumber pangan tradisional potensial yang dapat dikembangkan dalam diversifikasi pangan untuk mendukung ketahanan pangan lokal dan nasional. Sagu memiliki kadar karbohidrat yang cukup tinggi, rendah gula, dan lemak sehingga cocok bagi penderita diabetes. Karbohidrat dalam sagu mencapai 83gram dibandingkan kandungan lemak dan protein yang kurang dari 1 gram. Dengan kandungan nutrisi yang baik, maka mengonsumsi sagu memiliki manfaat sebagai anti oksidan, mengurangi risiko penyakit jantung, meningkatkan kinerja tubuh saat olahraga, dan baik untuk pertumbuhan anak (Alfons and Rivaie, 2011).

Kabupaten Luwu Utara merupakan penghasil sagu terbesar di Provinsi Sulawesi Selatan, pada tahun 2016 produksi sagu di Luwu Utara sebesar 1.938 ton dan luas area lahan sagu sebesar 1789 ha. Sedangkan, pada tahun 2017, luas areal lahan sagu mencapai 1,790 ha dengan hasil produksi 1.960 ton. Peningkatan produksi setiap tahunnya menjadikan Luwu Utara sebagai sentral sagu di Provinsi Sulawesi Selatan (Dirjenbun, 2017). Kurangnya pengetahuan masyarakat Desa Kapidi dalam mengolah sagu menjadi produk yang memiliki nilai jual tinggi dalam membangun perekonomian masyarakat yang baru dalam pembangunan yang bersifat people centered, participatory, empowerment and sustainable. Sehingga, sebagian besar masyarakat di Desa Kapidi memanfaatkan sagu sebagai pengganti makanan pokok yang diolah menjadi kapurung, sinole, dange, dan lain sebagainya (Chambers, 1995). Salah satu peluang untuk mengembangkan sagu yaitu membuat berbagai macam produk olahan yang bernilai ekonomis tinggi (Hasbi, A.R dan Sari, H., 2020).

Melihat daya tahan penyimpanan sagu yang mudah rusak, sehingga penulis menginovasikan sagu untuk dibuat menjadi makanan tradisional. Di Kabupaten Luwu Utara sagu dimanfaatkan sebagai pengganti makanan pokok dan kurang dimanfaatkan sebagai cemilan oleh karena itu penulis tertarik 
menginovasi sagu untuk dijadikan sebagai buroncong yang diberi nama Buroncong Tabaro. Buroncong merupakan kue tradisional khas Sulawesi Selatan yang hingga saat ini masih diminati banyak orang. Bentuknya mirip pukis yang berbentuk setengah lingkaran. Konon kue ini sudah dikenal sejak puluhan tahun lalu oleh masyarakat Sulawesi Selatan (Ramadan, 2015).

Setelah proses pembuatan produk, proses pemasaran merupakan hal yang sangat penting. Keberhasilan pemasaran tentunya tidak hanya dilihat dari berapa banyak produk yang habis terjual, akan tetapi bagaimana cara seorang produsen mempertahankan konsumen. Di era pandemi Covid-19 ini menjadi sebuah tantangan besar bagi seluruh pengusaha dalam meningkatkan keuntungan akan tetapi tidak sedikit pengusaha yang harus gulung tikar akibat pandemi ini (Sugiarti, Sari and Hadiyat, 2020). Tentunya semua itu tidak lepas dari cara seorang pengusaha dalam menentukan strategi pemasaran yang baik. Menurut Sari, H. dkk., (2020) berwirausaha di tengah pandemi Covid19 dapat dengan memanfaatkan berbagai potensi atau sumber daya alam. Tujuan dan target hasil kegiatan program pengabdian masyarakat ini adalah sebagai upaya dalam membantu masyarakat untuk memaksimalkan produksi makanan olahan berbahan lokal yang dapat dijadikan sebagai alternatif usaha dalam meningkatkan pendapatan masyarakat (Sari, H dan Hafid, A., 2019).

Perkembangan dunia digital yang semakin canggih tentunya harus dimanfaatkan seorang pengusaha dalam melakukan proses pemasaran. Media sosial telah mengubah cara orang berinteraksi satu sama lain. Dengan mengeksploitasi fungsionalitas sosial media, pengusaha dapat menggunakannya untuk mengelola aktivitas bisnis (Hilmiana, dkk., 2020). Media sosial menjadi wadah yang efektif dan efisien dalam memasarkan produk ke konsumen tanpa harus melakukan transaksi jual beli secara langsung (Kurniawati dan Arifin, 2015).

\section{METODE}

Implementasi kegiatan PKM-K pemberdayaan masyarakat telah disesuaikan dengan jadwal yang telah disiapkan sebelumnya. Kemudian pelaksanaannya diatur: 1) Program PKM-K Pemberdayaan Masyarakat dilaksanakan di Desa Kapidi Kecamatan Mappedeceng Kabupaten Luwu Utara Provinsi Sulawesi Selatan. Jarak antara Desa Kapidi dengan Ibu Kota Kabupaten Luwu Utara 11 km. Desa Kapidi terdiri atas 5 dusun dan 10 RT yaitu Dusun Kapidi, Dusun Sumber Ase, Dusun Sumber Ase Selatan, Dusun Sapuraga, dan Dusun Labeka. Program ini dilaksanakan pada tanggal 21 Januari 2021. 2) Adapun yang menjadi khalayak sasaran pada kegiatan pemberdayaan masyarakat ini adalah masyarakat Dusun Kapidi. 3) Alat pembuatan buroncong tabaro terdiri dari pisau, kompor gas, tabung gas, mixer, baskom, sendok, kemasan, saringan, dan cetakan buroncong. 4) Bahan pembuatan buroncong tabaro terdiri dari sagu, tepung terigu, gula pasir, kelapa, gula merah, pasta, air, telur, minyak, coklat, dan keju.

Adapun cara pembuatan dan pemasaran buroncong tabaro yaitu: 1) siapkan bahan baku (sagu), saring sagu hingga bersih; 2) siapkan tepung terigu gula pasir dan bahan lainnya; 3) campurkan semua bahan dan aduk adonan hingga merata; 4) siapkan cetakan buroncong untuk membakar adonan yang telah tercampur rata; 5) olesi minyak pada cetakan kemudian masukkan adonan ke dalam cetakan; 6) angkat buroncong jika sudah matang dengan merata; 7) apabila sudah dingin, kemas dengan kemasan yang telah disiapkan; 8) setelah dikemas lalu diberi label pada produk beserta kandungan vitamin dan mineral di dalamnya; 9) produk sudah siap dan selanjutnya masuk ke proses pemasaran secara online dilukukan dengan cara membuat akun baru di media sosial seperti Instagram dan Facebook @buroncong tabaro, serta membuat video singkat produk dan dibagikan di story media sosial yang telah disiapkan; 10) selain dipasarkan secara online, produk juga dipasarkan secara door to door (langsung mendatangi rumah masyarakat). 


\section{HASIL DAN PEMBAHASAN}

Hasil yang telah dicapai pada program PKM-K pengabdian masyarakat yang dilaksanakan di Desa Kapidi Kecamatan Mappedeceng Kabupaten Luwu Utara, sebagai berikut:

1. Persiapan dan Pengarahan

Setelah melakukan pengamatan, sosialisasi pembuatan buroncong tabaro mulai dilaksanakan dengan mengundang masyarakat setempat. Sosialisasi mengenai pentingnya pengetahuan dalam memanfaatkan sagu dilakukan dengan beberapa tahap:

a) Diskusi dengan masyarakat di Desa kapidi mengenai persiapan pemanfaatan sagu.

b) Kesepakatan mengenai waktu dan tempat melaksanakan pelatihan pembuatan buroncong tabaro.

c) Penetapan jadwal kegiatan pelatihan masyarakat mengenai pembuatan buroncong tabaro.

2. Penerapan

Program PKM-K pemberdayaan masyarakat ini dilakukan oleh 2 dosen, dibantu oleh 3 mahasiswa dan masyarakat setempat. Kegiatan ini tergabung dalam kelompok 01 Desa Kapidi, Kecamatan Mappedeceng, Kabupaten Luwu Utara. Adapun biaya yang dikeluarkan dalam pembuatan produk buroncong tabaro sebesar Rp 1.000.000. Tahap pembuatan produk buroncong tabaro yang telah berhasil dilakukan dapat dilihat pada gambar berikut:

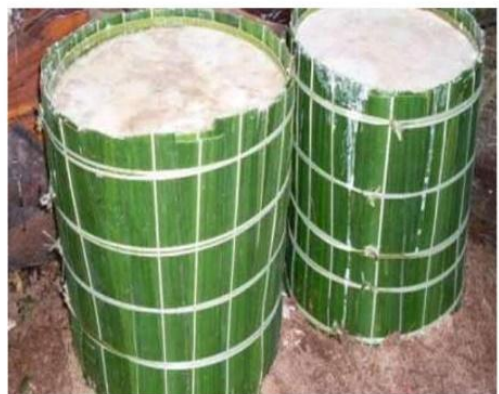

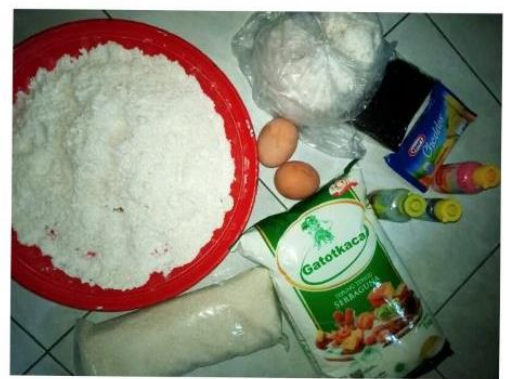

Gambar 1. Bahan-Bahan Pembuatan Buroncong Tabaro

(Sumber: Harmita Sari)
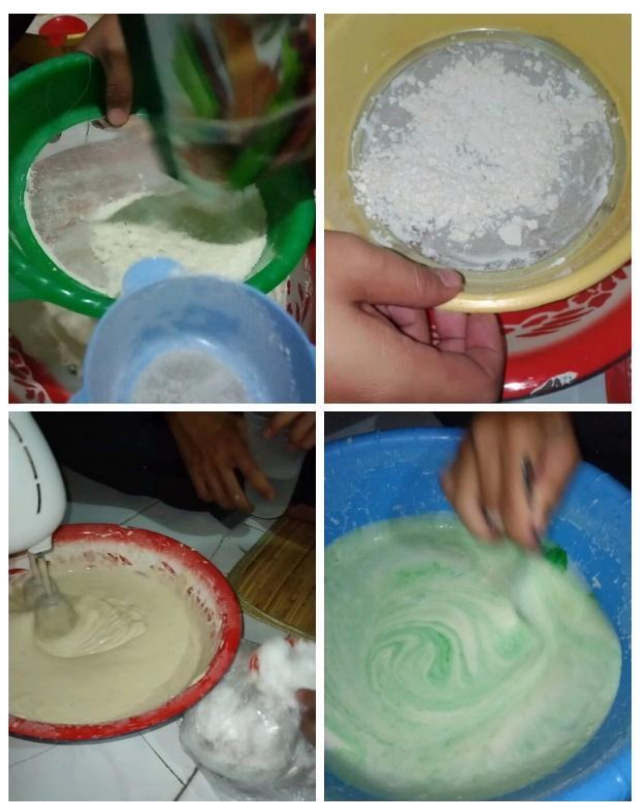

Gambar 2. Proses Pencampuran Bahan

(Sumber: Harmita Sari)
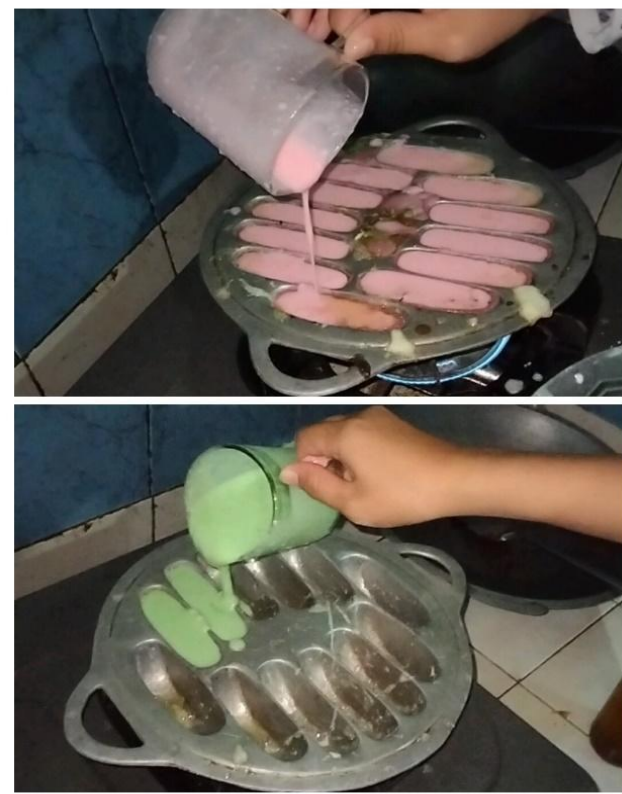

Gambar 3. Proses Pemasakan Buroncong Tabaro

(Sumber: Harmita Sari) 

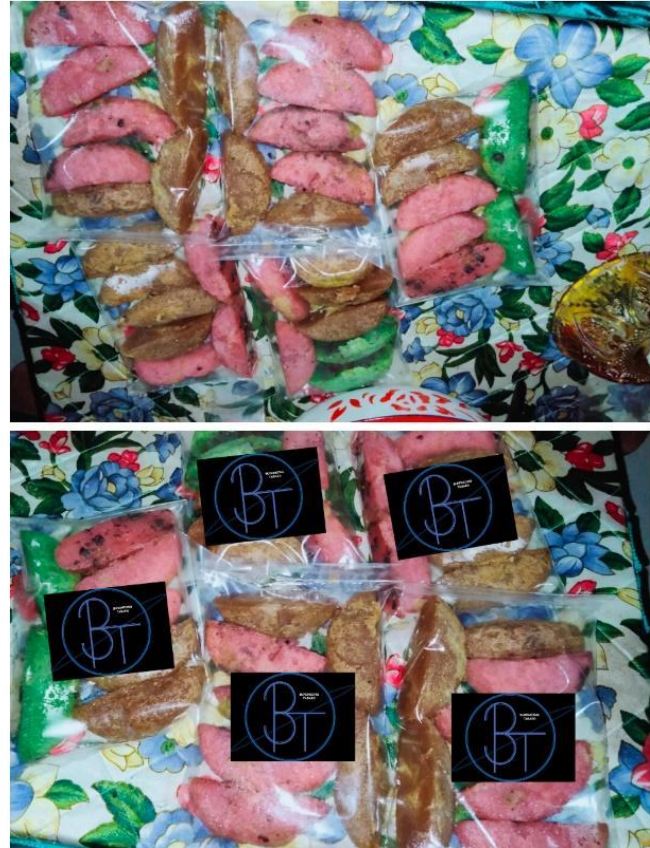

Gambar 4. Proses Pengemasan dan Pemberian Label Produk

(Sumber: Harmita Sari)
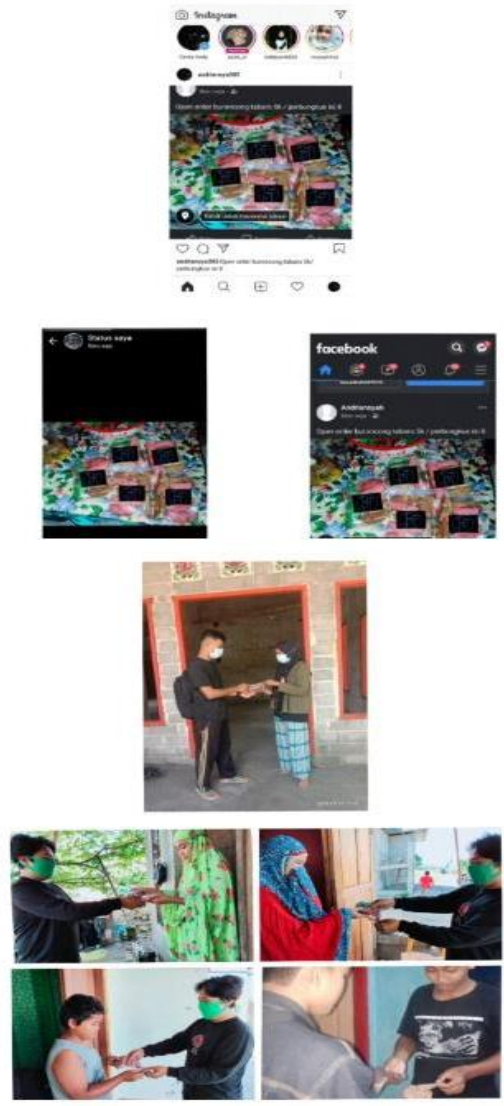

Gambar 5. Proses Pemasaran Produk Secara Door to Door dan Secara Online (Sumber: Harmita Sari)
3. Pemantauan dan Evaluasi

Menjalankan sebuah kegiatan pemberdayaan masyarakat di tengah pandemi Covid-19 khususnya di Desa Kapidi Kecamatan Mappedeceng Kabupaten Luwu Utara membutuhkan perencanaan yang terstruktur mulai dari segi pemantauan sampai pada evaluasi kegiatan. Planning yang baik tentunya dapat dilihat dari berbagai sisi seperti input, output, outcame, dan impact yang dihasilkan. Monitoring dibutuhkan untuk melihat perkembangan sebuah kegiatan secara menyeluruh. Serta evaluasi dibutuhkan untuk menilai dan menganalisis tingkat keberhasilan program pemberdayaan yang dilakukan. Pemberdayaan masyarakat dalam mengolah sagu menjadi buroncong tabaro (inovasi bahan dasar lokal menjadi makanan tradisional bergizi) telah terlaksana dengan baik sesuai dengan jadwal yang telah dibuat. Akan tetapi, dalam pelaksanaan kegiatan ini masih memiliki kekurangan-kekurangan yang perlu dibenahi di masa yang akan datang sehingga diharapkan kekurangankekurangan sebelumnya dapat menjadi kunci kesuksesan di masa depan.

\section{SIMPULAN}

Berdasarkan hasil implementasi PKM-K pemberdayaan masyarakat, dapat disimpulkan bahwa: 1) Kegiatan pemberdayaan masyarakat ini didukung oleh pemerintah daerah. 2) Program pemberdayaan ini merupakan sarana dalam memberdayakan masyarakat di Desa Kapidi Kecamatan Mappedeceng Kabupaten Luwu Utara. 3) Program pemberdayaan ini sebagai sarana dalam menggali potensi Desa Kapidi Kecamatan Mappedeceng Kabupaten Luwu Utara. 4) Program pemberdayaan ini sebagai sarana bagi masyarakat di Desa Kapidi Kecamatan Mappedeceng Kabupaten Luwu Utara dalam meningkatkan perekonomian di tengah Covid-19. 5) Program pemberdayaan ini sebagai sarana untuk meningkatkan kreativitas masyarakat dalam mengolah sesuatu yang ada di sekitarnya menjadi sebuah produk yang 
bermanfaat dan memiliki nilai jual, 6) Program pemberdayaan ini dapat menjadi sarana masyarakat dalam membangun jiwa berwirausaha yang tinggi.

\section{UCAPAN TERIMA KASIH}

Ungkapan terima kasih penulis ucapkan kepada Kepala LPPM Universitas Muhammadiyah Palopo yang telah mewadahi penulis dalam melaksanakan program pemberdayaan masyarakat. Kepada Aparat Desa dan Masyarakat Kecamatan Mappedeceng Desa Kapidi yang telah memberikan kerja sama yang baik sehingga program pemberdayaan masyarakat ini dapat selesai. Serta ucapan terima kasih juga dihaturkan kepada teman sejawat dan mahasiswa yang turut membantu dalam kegiatan pengabdian ini.

\section{DAFTAR PUSTAKA}

Alfons, J. B. and Rivaie, A. A. (2011) 'Sagu Mendukung Ketahanan Pangan Dalam Menghadapi Dampak Perubahan Iklim', Perspektif, 10(2), pp. 81-91.

Chambers, R. (1995) Poverty and Livelihoods:Whose Reality Counts diccussion. Brighton: Institute of Development Studies.

Darsana, P. (2019) 'Pattern of Social Relations In Transmigration Area Kapidi Village, Mappedeceng District, North Luwu Regency (Study Of Aspects Of Social Geography)', Jurnal La Geografia, 17(2).

Direktorat Jendral Perkebunan (Dirjenbun) (2017) Statistik Perkebunan Indonesia 2016-2018, Sekretariat Direktorat Jendral Perkebunan Kementrian Pertanian.

Hamid, U., Ridha, M. R. and Madjid, M. S. (2019) 'Pengolahan Sagu di Desa Cenning Kecamatan Malangke Barat Kabupaten Luwu Utara (1982-2017)', Jurnal Pemikiran Pendidikan dan Penelitian Kesejarahan, 6(3), pp. 109122. doi:10.26858/pattingalloang.v6i3.1 0551 .

Hasbi, Andi, R dan Sari, H. (2020) Atribut Produk yang Dipertimbangkan dalam
Pembelian Olahan Sagu di Kota Palopo. Jurnal Ilmu Pangan dan Hasil Pertanian 4 (1): 7-14.

Hilmiana, dkk. (2020). Pemberdayaan Masyarakat dalam Upaya Untuk Meningkatkan Taraf Kehidupan Melalui Inovasi Produk Bebas Bahan Kimia Berbahaya Di Desa Pamulihan Kabupaten Sumedang. Kumawula: Jurnal Pengabdian Kepada Masyarakat 3 (2): 358-366

Kurniawati, D. and Arifin, N. (2015) 'Strategi Pemasaran Melalui Media Sosial dan Minat Beli Mahasiswa', Jurnal Simbolika, I (2), pp. 193-198.

Luwuutarakab.go.id (2018) Desa Kapidi, kapidi.luwuutarakab.go.id. Available at: http://kapidi.luwuutarakab.go.id/blog/pa ge/gambaran-umum-desa (Accessed: 31 January 2021).

Ramadan, I. (2015) 'Kue Buroncong: Kue Khas Makassar Yang Legendaris', Beritamks.com, 28 August. Available at: https://beritamks.com/kue-buroncongkue-khas-makassar-yang-legendaris/. (Accessed: 31 January 2021).

Sari, Harmita. dkk. (2020) Integritas Pendidikan Menuai Wirausaha Di Era Pandemi Desa Buntu Karya Kecamatan Luwu Kabupaten Ponrang Selatan Provinsi Sulawesi Selatan. Selaparang. Jurnal Pengabdian Masyarakat Berkemajuan 4 (2): 34-40.

Sari, Harmita dan Hafid Anita. (2020) Pengembangan Usaha Kerupuk Amplang Bandeng untuk Memberdayakan Masyarakat Desa Polejiwa Kecamatan Malangke Barat Kabupaten Luwu Utara Provinsi Sulawesi Selatan. Jurnal Panrita Abdi: Jurnal Pengabdian Kepada Masyarakat 3 (2): 161-169.

Sugiarti, Y., Sari, Y. and Hadiyat, M. A. (2020) 'Peranan E-Commerce untuk Meningkatkan Daya Saing Usaha Mikro Kecil dan Menengah (UMKM) Sambal di Jawa Timur', Jurnal Kumawula: Jurnal Pengabdian Kepada Masyarakat, 3(2), pp. 298-309. doi: https://doi.org/10/24198/kumawula.v3i2. 28181. 